\title{
Pemberdayaan Komunitas Desa Tradisional Cireundeu Melalui Kemitraan Corporate Social Responsibility (CSR)
}

\author{
Gandhi Pharmacista \\ Fakultas Hukum Universitas Pasundang Bandung, \\ Jawa Barat, Indonesia \\ Email: gandhi.pharmacista@unpas.ac.id
}

\begin{abstract}
Abstrak. Developing Sundanese culture is a form of implementation of the vision and mission of Pasundan University as one of the implementation of the Tridharma of Higher Education. This study intends to examine the existence of the traditional village of Cireundeu. Cireundeu Village is an Adat Village that still maintains ancestral cultural existence, and has the potential to become an Ecotourism Village. One of the supporters is a natural factor that is still beautiful, and a culture that is still preserved, and a Sundanese philosophy that is the basis of its social life. The study was preceded by a literature study and then compared with field data taken from the results of direct observations and close study of business community which have used pyramid schemes. To prove the validity of the data, verification using qualitative analysis to identify communal and misused cultural values in recruitment patterns. Furthermore, there would be identification of empowerment of communal values in mediation activities. This background illustrates the importance of preserving culture, especially Sundanese culture. The specific objective of this study is to examine and find out what model can be applied to the Adat Village to become a Village of Ecotourism. The long-term goals to be achieved are expected by the existence of Cireundeu Indigenous Village Ecotourism to realize the cultural preservation of Adat Village communities in improving living standards, so that the target of this research is the formulation of community development models through CSR partnership models so as to realize Indigenous Village Ecotourism Cireundeu.
\end{abstract}

Keywords: Empowerment of Ecotourism, CSR (Corporate Social Responsibility) Partnership

\begin{abstract}
Abstrak. Mengembangkan budaya Sunda adalah bentuk implementasi dari visi dan misi Universitas Pasundan sebagai salah satu implementasi dari Tridharma Pendidikan Tinggi. Penelitian ini bermaksud untuk meneliti keberadaan desa tradisional Cireundeu. Desa Cireundeu adalah Desa Adat yang masih mempertahankan keberadaan budaya leluhur, dan berpotensi menjadi Desa Ekowisata. Salah satu pendukungnya adalah faktor alam yang masih indah, dan budaya yang masih dilestarikan, serta filosofi Sunda yang menjadi dasar kehidupan sosialnya. Penelitian ini didahului oleh studi literatur dan kemudian dibandingkan dengan data lapangan yang diambil dari hasil pengamatan langsung dan studi dekat komunitas bisnis yang telah menggunakan skema piramida. Untuk membuktikan validitas data, verifikasi menggunakan analisis kualitatif untuk mengidentifikasi nilai-nilai budaya komunal dan disalahgunakan dalam pola rekrutmen. Selanjutnya, akan ada identifikasi pemberdayaan nilai-nilai komunal dalam kegiatan mediasi. Latar belakang ini menggambarkan pentingnya melestarikan budaya, khususnya budaya Sunda. Tujuan khusus dari penelitian ini adalah untuk memeriksa dan mencari tahu model apa yang dapat diterapkan pada Desa Adat untuk menjadi Desa Ekowisata. Sasaran jangka panjang yang ingin dicapai diharapkan dengan adanya Ekowisata Desa Adat Cireundeu untuk mewujudkan pelestarian budaya masyarakat Desa Adat dalam meningkatkan taraf hidup, sehingga sasaran penelitian ini adalah perumusan model pengembangan masyarakat melalui model kemitraan CSR sehingga mewujudkan Ekowisata Desa Adat Cireundeu.
\end{abstract}

Kata kunci: Pemberdayaan Ekowisata, Kemitraan CSR (Corporate Social Responsibility)

\section{A. PENDAHULUAN}

Visi Universitas Pasundan adalah menjadi komunitas akademi internasional yang menjunjung nilai Sunda dan Islam di Tahun 2021, dengan misi menjaga, memelihara dan mengembangkan budaya Sunda. Melalui Tri Dharma Perguruan Tinggi yang antara lain melakukan penelitian dan pengabdian, bermaksud 
mengembangkan budaya Sunda khususnya Desa Adat yang terletak di Kampung Cirendeu yang terletak di lembah Gunung Kunci, Gunung Cimentang dan Gunung Gajahlangu, yang secara administratif termasuk wilayah Leuwi Gajah, Kecamatan Cimahi Selatan, Kota Cimahi.

Ekowisata

(Ecotourism)

merupakan hal yang menciptakan dan memuaskan suatu keinginan akan alam, mengeksploitasi potensi wisata untuk konservasi dan pembangunan serta mencegah dampak negatifnya terhadap ekologi, kebudayaan dan keindahan. (western, 1995:3). Dengan ekowisata diharapkan dapat menjamin keberlangsungan hidup pariwisata tanpa harus mengorbankan lingkungan.

Prinsip pembelajaran terhadap alam dan manfaatnya terhadap masyarakat, maka Desa Adat Cireundeu memiliki potensi dalam pengembangan ekowisata karena Cirendeu memiliki potensi kesenian dan makanan khas yang mampu menjadi daya tarik. Hal yang paling mendasar dalam pengelolaan tersebut yaitu untuk memasarkan potensi yang dimiliki yaitu dengan melakukan kerjasama/ bermitra dengan pelaku usaha dengan mekanisme Corporate social responsibility (CSR).

Kemitraan dalam lingkungan masyarakat yang merupakan sesuatu hal yang tidak asing

untuk diterapkan, dalam manajemen modern, baik dalam pengembangan sumberdaya manusia maupun pengembangan kelembagaan/ usaha, kemitraan merupakan salah satu strategi yang biasa ditempuh untuk mendukung keberhasilan implementasi manajemen modern (kamil, 2006 : 1). Kemitraan tidak sekedar diterjemahkan sebagai sebuah kerjasama, akan tetapi kemitraan memiliki bentuk, memiliki nilai strategis dalam mewujudkan keberhasilan suatu Lembaga dalam menerapkan manajemen modern termasuk dalam pengembangan ekowisata.

Kampung cireundeu tidak memposisikan desa/ kampungnya sebagai Obyek Daya Tarik Wisata (ODTW), tetapi lebih focus kepada desa yang masih memelihara tradisi lama yang telah mengakar yang diwariskan oleh tetua adat sejak jaman dahulu. Masyarakat kampung Cireundeu beranggapan bahwa sekecil apapun filosofi kehidupan yang diwariskan oleh nenek moyang mereka wajib untuk dipertahankan. Salah satu hal yang menarik yang masih dipertahankan warga desa adalah bahan makan pokok dan tradisi 1 (satu) Sura, serta filosofi "teu nyawah boga pare, teu boga pareu bago sangu, teu boga sangu bias dahar". Filosofi ini memberikan gambaran bahwa adanya beberapa wira usaha masyarakat setempat untuk memenuhi kebutuhan hidupnya, yang tidak hanya mengandalkan pertanian.

Kampung Adat Cireundeu memiliki potensi yang sangat baik menjadi daerah wisata, khususnya dengan konsep Ecowisata. Ecowisata atau ekotourisme merupakan salah satu kegiatan pariwisata yang berwawasan lingkungan dengan mengutamakan aspek konservasi alam, aspek pemberdayaan sosial budaya ekonomi masyarakat lokal, serta aspek pembelajaran dan pendidikan. Potensi yang dimiliki Desa Adat Cirendeu dapat dilihat dari faktor internal yakni melalui kekuatan dan kelemahan, serta dari sisi eksternal melalui peluang serta ancaman.

\section{Permasalahan}

Bagaimana model dan upaya yang dapat diterapkan dalam mengembangkan desa adat ecowisata 
cireundeu?

Bagaimaana model kemitraan yang dapat dikembangkan oleh Pemerintah Kota dan Pelaku usaha?

\section{Tujuan Penelitian}

Memberikan kontribusi kepada Pemerintahan Kota Cimahi, dalam mengembangkan konsep desat adat berbasis pada potensi alam, sehingga diharapkan mampu terwujud tujuan pelestarian budaya masyarakat desa adat dalam meningkatkan taraf hidup, dengan menyusun mekanisme pemberian CSR dalam menemukan model community development berupa naskah kemitraan dan tata cara pemberian CSR.

\section{Penjelasan Singkat:}

Ekowisata (Fandeli: 2002) sebagai suatu perpaduan dari berbagai minat yang tumbuh dari keprihatinan lingkungan, ekonomi dan social. Pada hakekatnya juga merupakan suatu konsep pengembangan wisata yang bertanggung jawab terhadap kelesatarian Area, memberi manfaat secraa ekonomi dan mempertahankan keutuhan budaya bagi masyarakat setempat.

Ekowisata terdiri dari tiga perspektif yakni sebagai: (Damanik dan Weber: 2006) (1) produk, merupakan semua atraksi yang berbasis pada sumber daya alam, (2) Pasar, merupakan perjalananyang diarahkan pada upaya-upaya pelestarian lingkungan dan (3) pendekatan pengembangan, merupakan metode pemanfaatan dan pengelolaan sumberdaya pariwisata secara ramah lingkungan.

Ekowisata adalah hal tentang menciptakan dan memuaskan suatu keinginan akan alam tentang mengeksploitasi potensi wisata untuk konservasi dan pembangunan serta upaya mencegah dampak negatifnya terhadap ekologi, kebudayaan dan keindahan (Linberg dan Hawkins: 1995). Beberapa factor yang menyebabkan berkembanganya ekowisata yaitu: (1) Ramah lingkungan: dampak yang rendah, mendorong pembangunan ekonomi berkelanjutan, perlindungan landscape termasuk pemandangan alam dan ekosistem alami, (2) Community Based, membuka peluang kerja dan berusaha serta pembangunan ekonomi masyarakat local (local community economic development), (3) sensistive secara budaya, terintegrasinya budaya local akibat aktivitas wisata yang berjalan yang akan memberikan manfaat terhadap wilayah akibat kunjungan, (4) viable secara ekonomi, memberikan manfaat finansial yang besar bagi pengelola dan masyarakat setempat (local).

Dalam pelaksanannya, dikenal lima prinsip ekowisata yaitu : (1) Nature Based, produk dan program berdasarkan kondisi alam (2) Ecologically Sustainable, manajemen dan pelaksanaan berkelanjutan (3) environmentally Educative, Pendidikan lingkungan bagi pengelola, masyarakat local dan pengunjung (4) local community based, bermanfaat bagi masyarakat local (5) Ecotourist based, kepuasan bagi pengunjung.

\section{B. METODE PENELITIAN}

Metode yang digunakan dalam penelitian ini adalah deskriptif analitik dengan menganalisis pola CSR yang diterapkan sekarang dan apa saja hambatan yang dapat ditemukan dalam upaya menyelesaikannya, sehingga dapat membantu meningkatkan kemitraan antara desa tradisional Cireundeu dan pemerintah kota Cimahi, serta pelaku bisnis dalam menerapkan CSR dengan berfokus pada pengembangan pengembangan masyarakat. 
C. HASIIL DAN PEMBAHASAN

Model dan upaya yang dapat diterapkan dalam mengembangkan desa adat ecowisata cireundeu

Secara umum community development dapat didefinisikan sebagai kegiatan pengembangan masyarakat yang diarahkan untuk memperbesar akses masyarakat untuk mencapai kondisi sosial-ekonomibudaya yang lebih baik apabila dibandingkan dengan sebelum terwujudnya kampung wisata. Dengan demikian masyarakat di tempat tersebut diharapkan menjadi lebih mandiri dengan kualitas kehidupan dan kesejahteraan yang lebih baik. (Budimants, 2003:40)

Secara umum visi dari community development adalah menciptakan lingkungan yang kondusif dan harmonis antara perusahaan dengan masyarakat sekitar wilayah kegiatan perushaaan (Budimanta, 2003:41), sedangkan misi dari aspek lingkungan social adalah memberikan nilai tambah pada nilai social ekonomi pemerintah daerah dan khususnya masyarakat sekitar. Selain itu misi lainnya adalah sebagai wahana interaksi antara masyarakat, pemerintah daerah dan pihak-pihak terkait (stakeholder) dengan perusahaan. Dengan terbinanya interaksi yang baik antara pihak-pihak tersebut diharapkan dapat dicegah sedidni mungkin komplik yang mungkin terjadi antara masyarakat dengan kegiatan perusahaan.

Community

development

memiliki 3 (tiga) karakter utama yang berbasis masyarakat (community based), berbasis sumber daya setempat (local resource based) dan berkelanjutan (sustainable). Sasaran yang ingin dicapai yaitu sasaran kapasitas masyarakat dan sasaran kesejahteraan. Peningkatan kapasitas masyarakat dapat dicapai melalui upaya pemberdayaan (empowerment) agar anggota masyarakat dapat ikut dalam proses pengembangan wilayah atau institusi penunjang dalam proses industri pariwisata, kesetaraan (equality) dalam arti program yang dikembangkan dalam bentuk kemitraan antara pemerintah Kota Cimahi dengan masyarakat setempat atau institusi sosial lokal, keamanan (security) dimana tumbuh rasa aman dari berbagai ancaman yang datang dari luar yang dikhawatirkan akan merusak tatanan budaya yang ada, keberlanjutan (sustainability), merupakan upaya pemerintah kota yang sungguh-sungguh dalam menciptakan harapan baru dari industri pariwisata dan kerjasama (cooperation) dengan berbagai lembaga sehingga menciptakan networking dalam upaya mendukung kampung wisata.

Jim Ife (2006:260) mengajukan definisi untuk berbagai istilah penting yang berkaitan dengan pengembangan komunitas di antaranya sebagai berikut : (1) Community-based services diterjemahkan

sebagai pelayanan yang bertumpu pada komunitas, adalah struktur dan proses pemenuhan kebutuhan insani (manusia) dengan mengutamakan sumberdaya, keahlian, dan kearifan komunitas itu sendiri. Definisi tersebut di atas erat kaitannya dengan berbagai istilah yang telah dikenal, misalnya: pembangunan yang bertumpu pada komunitas (community-based development) dan pembangunan perumahan yang bertumpu pada komunitas (community-based housing). (2) Community development padanan dalam Bahasa Indonesia sebagai pengembangan komunitas, adalah proses membangun, atau membangun kembali struktur komunitas insani di mana cara-cara baru untuk berhubungan antar pribadi, 
mengorganisasikan kehidupan sosial, dan memenuhi kebutuhan insani menjadi lebih dimungkinkan. (3) Community works padanan dalam Bahasa Indonesia sebagai pekerjaan pengembangan komunitas, adalah kegiatan atau praktek-praktek yang dilakukan oleh seseorang yang berupaya memfasilitasi proses pengembangan komunitas, tanpa memandang apakah orang tersebut menerima imbalan (bayaran/upah) maupun tidak.

dalam Community worker padanan
sebagai pekerja pengembangan komunitas, adalah setiap orang yang berupaya memfasilitasi proses pengembangan komunitas, tanpa memandang apakah seseorang itu memperoleh imbalan (bayaran/upah) maupun tidak.

Pengertian mendasar tersebut sejatinya dipahami pula oleh para pelaksana pengembangan komunitas oleh setiap corporate. Dengan kata lain, semua pihak yang terlibat sebagai pelaksana pengembangan komunitas baik secara langsung maupun tak langsung (bila perlu termasuk para pejabat manajemen puncak di suatu corporate) memahami instilah dasar pengembangan komunitas tersebut.

Dari pengertian tersebut harus dipahami bahwa setiap orang yang terlibat di dalam suatu corporate dalam kaitannya pelaksanaan upayaupaya corporate dalam rangkan pengembangan komunitas, khususnya Community Development Officer adalah upaya terhadap para pekerja dalam pengembangan komunitas.

Model kemitraan yang dapat dikembangkan oleh Pemerintah Kota dan Pelaku usaha
Dalam paradigma pembangunan berkelanjutan dimana diartikan sebagai pembangunan yang memenuhi kebutuhan masa kini tanpa mengurangi kemampuan generasi masa depan untuk memenuhi kebutuhannya, mempunyai 3 pilar utama (pertumbuhan ekonomi, pengentasan kemiskinan \& keberlanjutan) yang bersumber dari dua gagasan penting yaitu : (1) gagasan kebutuhan, khususnya kebutuhan esensial kaum miskin sedunia, yang harus diberi prioritas utama. (2) gagasan keterbatasan yang bersumber pada kondisi teknologi dan organisasi social masyarakat terhadap kemampuan lingkungan untuk memenuhi kebutuhan masa kini dan hari depan (Arif Budimanta \& Bambang Rudito, 2008: 28) . Jadi dalam paradigma ini, tujuan pembangunan ekonomi dan sosial harus diupayakan dengan keberlanjutannya. Artinya, tidak harus memenuhi kebutuhan saat ini tanpa memperdulikan kebutuhan masa yang akan datang, akan tetapi mengusahakan agar keberlanjutan pemenuhan kebutuhan tersebut pada masa selanjutnya pada generasi kemudian.

Ruang lingkup community development meliputi tiga aspek, yaitu : (a) Community Services; merupakan pelayanan perusahaan untuk memenuhi kepentingan masyarakat, seperti pembangunan fasilitas umum, pengembangan kualitas pendidikan, keagamaan dan lain sebaginya, (b) Community Empowering; adalah program-program yang berkaitan dengan memberikan akses yang lebih luas kepada masyarakat untuk menunjang kemandiriannya. (c) Community Relations yaitu kegiatankegiatan yang menyangkut pengembangan komunikasi dan informasi kepada para pihak yang terkait. (Budimanta, 2003: 43) 
Adapun peserta dari program community development ini seyogyanya difokuskan pada masyarakat yang terkait dampak langsung dari kegiatan perusahaan (Budimanta, 2003: 44)

Berkaitan dengan hal tersebut di atas, industri tidak lagi dituntut untuk hanya mewujudkan citranya melalui kampanye yang baik namun juga harus mampu menunjukkan akuntabilitasnya kepada kepentingan publik. Pengusahaan yang dapat bertanggungjawab akan memperhatikan corporate social responsibility semaksimal mungkin, yang didukung oleh good corporate governance dan good governance. Disinilah menjadi penting untuk kemudian membicarakan program community development sebagai wujud social responsibility perusahaan.

GCG diperlukan untuk mendorong terciptanya pasar yang efisien, transparan dan konsisten dengan peraturan perundang-undangan. Penerapan GCG perlu di dukung oleh 3 (tiga) pilar yang saling berhubungan, yaitu Negara dan perangkatnya sebagai regulator, dunia usaha sebagai pelaku pasar, dan masyarakat sebagai pengguna produk dan jasa dunia usaha (Komisi Nasional Kebijakan Governance, 2006: 3). Prinsip dasar yang harus dilaksanakan oleh masingmasing pilar adalah : (1) Negara dan perangkatnya menciptakan peratuan perundang-undangan yang menunjang iklim usaha yang sehat, efisien dan transparan, melaksanakan peraturan perundang-undangan dan penegakan hukum secara konsisten (consistent law enforcement), (2) dunia usaha sebagai pelaku pasar menerapkan GCG sebagai pedoman dasar pelaksanaan usaha, (3) masyarakat sebagai pengguna produk dan jasa dunia usaha serta pihak yang terkena dampak dari keberadaan perusahaan, menunjukkan kepedulian dan melakukan kontrol sosial (social control) secara obyektif dan bertanggung jawab.

Undang-Undang Nomor 40 Tahun 2007 tentang Perseroan Terbatas, Pasal 1 Ayat (3) menjelaskan bahwa "tanggung jawab sosial dan lingkungan adalah komitmen Perseroan untuk berperan serta dalam pembangunan ekonomi berkelanjutan guna meningkatkan kualitas kehidupan dan lingkungan yang bermanfaat, baik bagi perseroan sendiri, komunitas setempat, maupun masyarakat pada umumnya. Didalam Bab V Tanggung Jawab Sosial dan Lingkungan, Pasal 74 Undang-Undang Perseroan Terbatas ayat (1) menjelaskan bahwa perseroan yang menjalankan kegiatan usahanya di bidang dan/ atau berkaitan dengan sumber daya alam wajib melaksanakan tanggung jawab sosial dan lingkungan, kemudian dalam ayat (2) menjelaskan tanggung jawab sosial dan lingkungan sebagaimana dimaksud pada ayat (1) merupakan kewajiban Perseroan yang dianggarkan dan diperhitungkan sebagai biaya Perseroan yang pelaksanaannya dilakukan dengan memperhatikan kepatutan dan kewajaran, kemudian di dalam ayat (3) menjelaskan bahwa Perseroan yang tidak melaksanakan kewajiban sebagaimana dimaksud pada ayat (1) dikenai sanksi sesuai dengan ketentuan peraturan perundang-undangan, serta di dalam ayat (4) menjelaskan ketentuan lebih lanjut mengenai tanggung jawab sosial dan lingkungan diatur dengan Peraturan Pemerintah.

Setiap perusahaan harus memastikan bahwa asas GCG diterapkan pada setiap aspek bisnis dan semua jajaran perusahaan. Asas GCG yaitu transparansi, akuntabilitas, responsibilitas, independensi serta kesetaraan dan kewajaran diperlukan 
untuk mencapai kinerja yang berkesinambungan dengan tetap memperhatikan kepentingan.

pemangku

Dalam praktik penyelenggaraan pemerintahan di Indonesia pascagerakan reformasi nasional, prinsip-prinsip penyelenggaraan pemerintahan yang baik tertera dalam Undang-Undang Nomor 28 Tahun 1999 tentang Penyelenggaraan Negara yang Bersih dan Bebas Korupsi, Kolusi, dan Nepotisme. Dalam pasal 3 dan penjelasannya ditetapkan asas umum pemerintahan yang baik mencakup hal-hal berikut : (1) Asas kepastian hukum, yaitu asas dalam negara hukum yang mengutamakan landasan peraturan perundangundangan, kepatutan, dan keadilan dalam setiap kebijakan penyelenggara Negara, (2) Asas tertib penyelenggaraan negara, yaitu asas yang menjadi landasan keteraturan, keserasian, dan keseimbangan dalam pengendalian penyelenggaraan Negara, (3) Asas kepentingan umum adalah asas yang mendahulukan kesejahteraan umum dengan cara yang aspiratif, akomodatif, dan selektif, (4) Asas keterbukaan, yaitu asas yang membuka diri terhadap hak masyarakat untuk memperoleh informasi yang benar, jujur, dan tidak diskriminatif tentang penyelenggaraan negara dengan tetap memperhatikan perlindungan atas hak asasi pribadi, golongan, dan rahasia Negara, (5) Asas proporsionalitas, yaitu asas yang mengutamakan keseimbangan antara hak dan kewajiban penyelenggara Negara, (6) Asas profesionalitas, yaitu asas yang mengutamakan keahlian berlandaskan kode etik dan ketentuan peraturan perundangundangan yang berlaku, (7) Asas akuntabilitas, yaitu asas yang menentukan bahwa setiap kegiatan dan hasil akhir kegiatan penyelenggara negara harus dapat dipertanggungjawabkan kepada masyarakat atau rakyat sebagai pemegang kedaulatan tertinggi negara sesuai dengan ketentuan peraturan perundang-undangan yang berlaku (Eddy Utomo: http://pknips.blogspot.co.id/2016/03/pemerintah an-yang-baik-good-governance. html. diunduh pada tanggal 08 November 2016).

\section{KESIMPULAN DAN SARAN}

Desa wisata adalah bentuk integrasi dan atraksi, akomodasi dan fasilitas pendukung yang disajikan dalam struktur kehidupan masyarakat yang terintegrasi dengan prosedur dan tradisi yang berlaku.

Ada 2 (dua) konsep utama dalam komponen pariwisata, yaitu, pertama adalah akomodasi dan yang kedua adalah daya tarik. Pengembangan desa wisata harus direncanakan secara struktural dan hati-hati agar dampak yang dihasilkan dapat dikendalikan. Beberapa pendekatan dalam menyusun konsep pengembangan desa menjadi desa wisata adalah dengan pendekatan pasar untuk pengembangan desa wisata yang meliputi interaksi tidak langsung, interaksi setengah langsung, interaksi langsung, dan menentukan kriteria desa wisata dan pendekatan fisik. untuk mengembangkan desa wisata yang mencakup konservasi yang memiliki nilai tinggi dan budaya dan arsitektur dan mengubah fungsi rumah menjadi museum desa, melestarikan seluruh desa, mengembangkan bentuk akomodasi, mengembangkan fasilitas pendukung, membangun struktur dalam mengelola fasilitas yang ada, dan mengembangkan desa-desa wisata berdasarkan satu ciri budaya yang secara tradisional melekat pada sebuah desa.

Desa tradisional Cireundeu 
memiliki potensi untuk
mengembangkan berbasis ekowisata dengan mempromosikan keindahan alam dan budaya yang masih turun temurun, yang bertujuan untuk melestarikan warisan leluhur, dengan cara:

Sebuah.

Tingkatkan

keterampilan masyarakat setempat sehingga mereka dapat melihat peluang dalam bisnis pariwisata, seperti meningkatkan keterampilan dalam membuat barang-barang kerajinan tangan yang digunakan sebagai oleholeh, makanan asli yang berasal dari desa, dan seni asli Sunda yang masih melekat pada desa tradisional Cireundeu

Perlunya studi kemitraan dalam pengembangan ekowisata, sehingga ada pemahaman antara pemerintah kota dan masyarakat dan pelaku bisnis, untuk mengambil bagian dalam pelestarian budaya.

\section{UCAPAN TERIMA KASIH}

Penelitian ini didukung oleh Universitas Pasundan, khususnya Fakultas Hukum yang membantu penelitian ini pada tahun 2017 saya ingin mengucapkan terima kasih kepada rekan-rekan kami dari Universitas Pasundan, yang memberikan wawasan dan keahlian yang sangat membantu penelitian, meskipun mereka mungkin tidak setuju dengan semua interpretasi / kesimpulan dari makalah ini.

Akhirnya, kami sangat berterima kasih kepada Tuhan Yang Maha Kuasa yang telah memberi kami kekuatan dan kesehatan dalam menyelesaikan jurnal ini, dan kami tidak lupa mengucapkan terima kasih kepada pihak-pihak yang tidak dapat kami sebutkan satu per satu, serta lembaga kami di, dan membantu/ berkontribusi pemikiran dalam proses mempersiapkan jurnal ini

\section{DAFTAR PUSTAKA}

Budimanta, Arief \& Rudito, Bambang. 2003. Pedoman Pengembangan Masyarakat Industri Dan Sumber Daya Mineral.

- 2004. Corporate Social Responsibility: Jawaban Model Pembangunan Indonesia Masa Kini.

David, Western. 1995. Ekotourisme: Petunjuk Untuk Perencanaan \& Pengelolaan. Jakarta: The Ecotourism Society North Benington, Vermont.

Fandeli, C. 2002. Perencanaan Kepariwisataan Alam. Yogyakarta: Fakultas Kehutanan Universitas Gadjah Mada.

Ife, Jim. 2006. Human Rights from Below: Achieving Rights Through Community Development. Australia: Cambridge University Press.

Janianton Damanik \& Helmut F. Weber. 2006. Perencanaan Ekowisata. Yogyakarta: Pusbar UGM \& Andi Yogyakarta.

Lindberg, and Donald E K dan Hawkins. 1993. Ecotourism As a Worldwide Phenomenon. Edited by North Bennington. The Ecotourism Society.

Mustofa, Kamil. n.d. "Strategi Kemitraan Dalam Membangun PNF Melalui Pemberdayaan Masyarakat (Model, Keunggulan Dan Kelemahan)." http://file.upi.edu/Direktori/SPS/ PRODI.PENDIDIKAN_LUAR_ SEKOLAH/196111091987031MUSTOFA_KAMIL/Bhaan_kul iah/KEMITR 1.PDF.

Utomo, Eddy. 2016. "Pemerintah Yang Baik (Good Governace)." Blogspot.Co.Id. 2016. http://pkn- 
ips.blogspot.co.id/2016/03/peme rintahan-yang-baik-goodgovernance. html.

Indonesian Civil Law No. 402007 limited Liability

Indonesian Civil Law No. 281999

Corruption 